\title{
What are the perspectives of cannabidiol (CBD) for the treatment of glioblastoma?
}

\section{Gerhard Nahler* \\ Clinical Investigation Support GmbH, Kaiserstrasse, Austria}

Glioblastoma (GBM) or WHO grade IV astrocytoma is the most aggressive form of brain tumors and ranks among the deadliest types of cancer. It is also the most common malignant primary brain tumor. Its high proliferation rate and invasiveness, together with a considerable cellular and molecular heterogeneity, is a challenge for treatment. Current therapeutic strategies include surgery, chemotherapy, radiotherapy and combinations thereof. Temozolomid (TMZ) is considered as the benchmark for treatment but resistance to TMZ antitumoral action is frequent and contributes to the overall poor prognosis. After second line treatment with TMZ, median survival is around 5.1 to 13 months, depending on the study [1].

Anti-cancer effects of cannabinoids have long been argued. Scientific evidence goes back to 1974 at the Medical College of Virginia at the behest of the US government. In an attempt to provide data proving a link between cannabis and cancer risk in order to provide evidence justifying international prohibition, the contrary was observed [2]. With the detection of the endocannabinoid system in the early 90 ies, much insight was gained into the mechanisms of cannabinoids; a number of preclinical studies, in vitro as well as in vivo, confirmed the antineoplastic properties of both, phyto- and synthetic cannabinoids. Out of the phytocannabinoids, delta-9-tetrahydrocannabinol (THC) and cannabidiol (CBD) are the best studied substances. These two cannabinoids differ in their effective doses: Common oral doses of THC are in the order of two to three times $2.5 \mathrm{mg}$ to $10 \mathrm{mg} /$ day, whereas CBD is currently administered in a dose of 100 to $300 \mathrm{mg}$ twice daily; doses up to $1,500 \mathrm{mg}$ CBD have been well tolerated. THC has some inherent clinical drawbacks due to its psychotropic properties, in addition to increased anxiety and withdrawal symptoms after high doses and down-regulation of $\mathrm{CB} 1$ receptors $[3,4]$. In contrast, $\mathrm{CBD}$ is free from such constraints. Furthermore, THC is unsuited for children and adolescents. Although rare when compared with adults, brain tumors are the most common solid tumors in children.

Cannabinoids demonstrate tumor-specific cytostatic/cytotoxic effects modulating the growth of glioblastoma by multiple, often overlapping mechanisms that repeatedly showed synergism when combined with other treatments. In particular CBD has been reported to activate apoptosis via oxidative stress (increase in ROS production in tumor cells [5]), and to inhibit tumor cell proliferation by inducing cell cycle arrest. Furthermore, CBD inhibits tumor angiogenesis and infiltration/ invasion even at low concentrations and abrogates resistance of glioma stem-like cells to BCNU (carmustine) therapy [6]. Cannabinoids are synergistic with chemotherapy and also with gamma-irradiation [7-9]. So far, experiments suggest that high doses of cannabinoids are necessary in order to achieve anti-tumor effects. In the inverse, low concentrations or doses respectively, may even enhance the growth of glioma, lung and breast cancer cells in vitro
[10] and in vivo [11,12]. In addition to the tissue concentration and experimental conditions, effects depend very much upon the nature of the tumor cells. Although preclinical results cannot be transferred oneto-one to the situation in man, dose-dependency has been observed not only in vitro but also in animal experiments. A condensed overview on available in vivo results with $\mathrm{CBD}$ is presented in table 1.

As can be seen, all experiments used relatively high doses of cannabinoids and all reported a significant effect on tumor growth and/or survival; in one experiment, one of five animals were even completely free of cancer after receiving $15 \mathrm{mg} \mathrm{CBD} / \mathrm{kg}$ [13].

In man, results of glioblastoma treatment with cannabinoids are still limited and restricted to the pioneering study of Guzman et al. [15] with THC, and a recent phase I/II - study that administered nabiximols, a 1:1 combination of two refined extracts, each containing around 65$70 \%$ CBD or THC respectively, as add-on treatment to TMZ [16]. In the first study, THC was infused into the resection cavity of nine freshly operated patients with treatment-resistant glioblastoma. Overall, the initial dose of THC administered to the patients was 20 to $40 \mathrm{mg}$ at day 1 , increasing progressively for 2 to 5 days up to 80 to $180 \mathrm{mg} /$ day which corresponds to a very high, local dose. Most interesting, in those five patients that received more than one cycle (median duration per cycle: 10 days), three patients demonstrated a temporary reduction of tumor proliferation.

In the second study, patients with recurrent glioblastoma received a combination of $\mathrm{CBD} / \mathrm{THC}$ up to a maximum tolerated dose (maximum 12 sprays per day, i.e. up to $30 \mathrm{mg}$ CBD $+32.4 \mathrm{mg}$ THC per day) or placebo, in combination with dose-intense TMZ. The one-year survival rate was significantly higher $(83 \%)$ in the group that received nabiximols (12 patients) compared to the placebo-group ( 9 patients, $53 \%$ survived). Median survival was over 550 days compared to 369 (i.e. +6 months). There is reason to assume that a higher ratio in favor of CBD such as $4 / 1$ to $5 / 1$ (CBD/THC) could achieve similar, may be even better results with a better tolerance as has been suggested by a very recent animal study [17]. With respect to the difference in effective doses between CBD and THC mentioned above, this animal experiment could be particularly relevant for man.

${ }^{\star}$ Correspondence to: Gerhard Nahler, Clinical Investigation Support GmbH Kaiserstrasse 43, 1070 Wien, Austria, Tel: +43-152-340-150, E-mail: nahler@aon.at

Key words: cannabidiol, CBD, cannabinoids, delta-9-tetrahydrocannabinol, THC, glioblastoma

Received: September 26, 2018; Accepted: October 05, 2018; Published: October 10,2018 
Table 1. Results of CBD and CBD: THC combinations in animal models of glioma

\begin{tabular}{|c|c|c|c|}
\hline Treatment & Model & Results & Ref. \\
\hline $\begin{array}{l}\text { CBD peritumoral, } \\
\sim 25 \mathrm{mg} \text { s.c. } / \mathrm{kg} / \mathrm{d}, 5 \mathrm{~d} / \mathrm{w} \text { for } 23 \mathrm{~d},\end{array}$ & $\begin{array}{l}\text { U87MG astro-cytoma s.c. xenograft, } \\
8 \mathrm{w} \text { old nude mice }\end{array}$ & $\sim 70 \%$ regression at day 18 , but $\sim 50 \%$ regression at day $23 /$ end; & [12] \\
\hline $\begin{array}{l}\text { CBD + THC (each } \sim 2 \mathrm{mg} \text { i.p. } / \mathrm{kg} \text { ) on } \\
\text { day } 9,13,16 \text { after tumor implantation; } \\
\text { X-ray ( } 4 \text { Gy) on } \mathrm{d} 9 \text {; } \\
\text { CBD-BDS }(63.5 \% \text { CBD, } 3.6 \% \text { THC, } \\
5.2 \% \text { CBC) or THC-BDS }(65.4 \% \text { THC, } \\
0.4 \% \text { CBD, } 1.8 \% \text { CBC) }\end{array}$ & $\begin{array}{l}\text { mouse glioma GL261 cells, } \\
\text { orthotopically implanted, C57BL } 6 \\
\text { mice ( } \sim 9 \mathrm{w} \text { old) }\end{array}$ & $\begin{array}{l}85 \% \text { decrease of tumor volume and of vascularisation on d21 (animals sacrificed); CBD + } \\
\text { THC reduced progression, further enhanced by irradiation (stagnant tumor sizes throughout } \\
\text { the experiment); X-rays alone had no dramatic effect; } \\
\text { In vitro effects (human glioma cell lines T98G, U87MG, mouse glioma GL261) differed: } \\
\text { THC-BDS was more efficacious than THC-P; conversely, CBD-P was more efficacious } \\
\text { than CBD-BDS; pretreatment of cells with THC-P + CBD-P together for } 4 \text { hours before } \\
\text { irradiation increased radiosensitivity (P-pure }>96 \% \text { ) }\end{array}$ & {$[8]$} \\
\hline CBD 15 mg i.p. $/ \mathrm{kg}, 5$ days $/ \mathrm{w}$ & athymic, GSC-bearing nu/nu mice & $\begin{array}{l}\text { significant increase in the survival; initial response to CBD (reduction of tumor size at d22), } \\
\text { followed by tumor resistance } 1 \mathrm{w} \text { later, } \mathrm{d} 29 \text { ) }\end{array}$ & {$[5]$} \\
\hline $\begin{array}{l}\text { CBD, } \\
15 \mathrm{mg} \text { i.p. } / \mathrm{kg}, 5 \mathrm{~d} / \mathrm{w} \text { for } 28 \text { days }\end{array}$ & $\begin{array}{l}\text { U251 glioblastoma cells, intracranial } \\
\text { xenograft, mice }\end{array}$ & $\begin{array}{l}295 \% \text { decrease of tumor area; in } 1 / 5 \text { mice treated no tumor cells were observed in any of the } \\
\text { brain regions analyzed; }\end{array}$ & {$[13]$} \\
\hline $\begin{array}{l}\text { CBD or THC } 7.5 \mathrm{mg} / \mathrm{kg} / \mathrm{d} \text {; or CBD + } \\
\mathrm{THC} 7.5 \mathrm{mg} \text { each } / \mathrm{kg} / \mathrm{d} \text {; or } 15 \mathrm{mg} \mathrm{THC} / \\
\mathrm{kg} / \mathrm{d} \text {; or CBD }+\mathrm{THC} \text { each } 3.7 \mathrm{mg} / \mathrm{kg} / \mathrm{d} \\
+\mathrm{TMZ} 5 \mathrm{mg} / \mathrm{kg} / \mathrm{d} \text {, peritumoral, } 15 \mathrm{~d}\end{array}$ & $\begin{array}{l}\text { human glioma U87MG or T98G cells, } \\
\text { s.c. xenograft, nude mice }\end{array}$ & $\begin{array}{l}7.5 \mathrm{mg} \mathrm{CBD} / \mathrm{kg} \text { was slightly more effective than } 7.5 \mathrm{mg} \mathrm{THC} / \mathrm{kg} ; \mathrm{THC}+\mathrm{CBD} \text { (each } 7.5 \\
\mathrm{mg} / \mathrm{kg} \text { ) was most effective and similar to } 15 \mathrm{mg} \mathrm{THC} / \mathrm{kg} \text {; tumor volume was stable on day } \\
14 \text { and } 15 \text {; further enhancement by combination of THC with } 5 \mathrm{mg} \mathrm{TMZ} / \mathrm{kg} \text {; the triple } \\
\text { combination of THC, CBD, and TMZ strongly reduced the growth of glioma xenografts and } \\
\text { overcomed the resistance to TMZ antitumoral action }\end{array}$ & {$[14]$} \\
\hline
\end{tabular}

BDS: Botanical Drug Substance (extract); B.W: Body Weight; CBC - Cannabichromene; d: day; GIC - Glioma Initiating Cells; exchangeable with GSC: Glioma Stem Cells; i.p.: intraperitoneal; nu: nude; s.c.: subcutaneous; TMZ: Temozolomide; w: week

In addition to the antineoplastic action, $\mathrm{CBD}$ has been reported to reduce nausea and/or vomiting [18], as well as having anti-depressive and analgesic properties. A very recent case series on glioma patients confirmed these effects [19].

In summary, combination of various anticancer regimens that include cannabinoids seems to be at present the most promising strategy for the treatment of glioblastoma and for improving the survival of patients. The large therapeutic range and excellent tolerance makes $\mathrm{CBD}$ an interesting substance for combination with temozolomid, radiation and/or other cannabinoids.

\section{References}

1. Gallego O (2015) Nonsurgical treatment of recurrent glioblastoma. Curr Oncol 22: e273-e281. [Crossref]

2. Munson AE, Harris LS, Friedman MA, Dewey WL, Carchman RA (1975) Antineoplastic activity of cannabinoids. J Natl Cancer Inst 55: 597-602. [Crossref]

3. Burston JJ, Wiley JL, Craig AA, Selley De, Sim-SelleyLJ (2010) Regional enhancement of cannabinoid CB\&\#8321; receptor desensitization in female adolescen rats following repeated Delta-tetrahydrocannabinol exposure. Br J Pharmacol 161: 103-112. [Crossref]

4. Childs E, Lutz JA, de Wit H (2017) Dose-related effects of delta-9-THC on emotional responses to acute psychosocial stress. Drug Alcohol Depend 177: 136-144. [Crossref]

5. Singer E, Judkins J, Salomonis N, Matlaf L, Soteropoulos P, McAllister S, et al. (2015) Reactive oxygen species-mediated therapeutic response and resistance in glioblastoma. Cell Death Dis 6: e1601. [Crossref]

6. Dumitru CA, Sandalcioglu IE, Karsak M (2018) Cannabinoids in glioblastoma therapy: new applications for old drugs. Front Mol Neurosci 11:159. [Crossref]

7. Ivanov VN, Wu J, Hei TK (2017) Regulation of human glioblastoma cell death by combined treatment of cannabidiol, $\gamma$-radiation and small molecule inhibitors of cell signaling pathways. Oncotarget 8: 74068-74095. [Crossref]

8. Scott KA, Dalgleish AG, Liu WM (2014) The combination of cannabidiol and D9tetrahydrocannabinol enhances the anticancer effects of radiation in an orthotopic murine glioma model. Mol Cancer Ther 13: 2955-2967. [Crossref]
9. Yasmin-Karim S, Moreau M, Mueller R, Sinha N, Dabney R et al. (2018) Enhancing the therapeutic efficacy of cancer treatment with cannabinoids. Front Oncol 8:114. [Crossref]

10. Hart S, Fischer OM, Ullrich A (2004) Cannabinoids induce cancer cell proliferation via tumor necrosis factor alpha-converting enzyme (TACE/ADAM17)-mediated transactivation of the epidermal growth factor receptor. Cancer Res 64: 1943-1950. [Crossref]

11. McKallip RJ, Nagarkatti M, Nagarkatti PS (2005) D-9-tetrahydrocannabinol enhances breast cancer growth and metastasis by suppression of the antitumor immune response. J Immunol 174: 3281-3289. [Crossref]

12. Massi P, Vaccani A, Ceruti S, Colombo A, Abbracchio MP, et al. (2004) Antitumo effects of cannabidiol, a non-psychoactive cannabinoid, on human glioma cell lines. $J$ Pharmacol Exp Ther 308: 838-845. [Crossref]

13. Soroceanu L, Murase R, Limbad C, Singer E, Allison J, et al. (2013) Id-1 is a key transcriptional regulator of glioblastoma aggressiveness and a novel therapeutic target. Cancer Res 73: 1559-1569. [Crossref]

14. Torres S, Lorente M, Rodriguez-Fornes F, Hernandez-Tiedra S, Salazar M, et al. (2011) A combined preclinical therapy of cannabinoids and temozolomide against glioma. Mol Cancer Ther 10: 90-103. [Crossref]

15. Guzman M, Duarte MJ, Blazquez C, Ravina J, Rosa MC, et al. (2006) A pilot clinical study of Delta9-tetrahydrocannabinol in patients with recurrent glioblastoma multiforme. Brit J Cancer 95: 197-203. [Crossref]

16. Twelves C, Short S, Wright S (2017) A two-part safety and exploratory efficacy randomized double-blind, placebo-controlled study of a 1:1 ratio of the cannabinoids cannabidiol and delta-9-tetrahydrocannabinol (CBD:THC) plus dose-intense temozolomide in patients with recurrent glioblastoma multiforme (GBM). J Clin Oncol 35: 2046-2046.

17. Lopez-Valero I, Saiz-Ladera C, Torres S, Hernández-Tiedra S, García-Taboada E, et al. (2018) Targeting glioma initiating cells with a combined therapy of cannabinoids and temozolomide. Biochem Pharmacol pii: S0006-2952(18)30389-30397. [Crossref]

18. Rock EM, Bolognini D, Limebeer CL, Cascio MG, Anavi-Goffer S, et al. (2012) Cannabidiol, a non-psychotropic component of cannabis, attenuates vomiting and nausea-like behaviour via indirect agonism of 5-HT(1A) somatodendritic autoreceptors in the dorsal raphe nucleus. Br J Pharmacol 165: 2620-2634. [Crossref]

19. Likar R, Köstenberger M (2018) Cannabidiol reduziert Depression und Müdigkeit be Patienten mit Hirntumoren. Universum Innere Medizin 2018;10 (in press). [text in German]

Copyright: $(02018$ Nahler G. This is an open-access article distributed under the terms of the Creative Commons Attribution License, which permits unrestricted use, distribution, and reproduction in any medium, provided the original author and source are credited. 